\title{
THE IMPACT OF TAX SYSTEM ON GLOBAL COMPETITIVENESS. ANALYSIS ON THE LEVEL OF EUROPEAN UNION MEMBER STATES
}

\author{
Mihaela Brînduşa Tudose \\ "Petre Andei" University of Iaşi \\ brindusatudose@gmail.com \\ Constantin Străpuc \\ "Ştefan cel Mare" University of Suceava \\ strapuc@gmail.com
}

\begin{abstract}
Summarizing the results of theoretical and empirical research, the paper aims to analyze the impact of tax system on global competitiveness through the following three variables: taxation on incentives to invest; total tax rate and taxation on incentives to work. Summarizing the analysis to the European Union member states, the paper presents rankings and provides interpretations for each case. Luxembourg is the country where there is registered: a) the biggest impact on competitiveness of tax policies supporting investment, b) the largest fiscal affordability (measured by GDP/capita and total tax rate) and c) the most generous labor taxation system in the EU. However, in the ranking realized based on the global competitiveness index Luxembourg ranks on the $22^{\text {nd }}$ place, on the first place being Finland.
\end{abstract}

\section{Keywords}

the global competitiveness index; efficiency; innovation; the total tax rate; fiscal facilities

\section{JEL Classification}

F02; F14

\section{Introduction}

The analysis of global competitiveness permits the assessment of the extent to which various economies of the world countries have managed to meet the challenges. Regardless of their size, the economies - dependent on foreign economic exchanges were confronted with unusual experiences; the economic crisis has generated a crisis of public finances which - on the background of political deadlock - has made it more difficult to recover even for the most advanced economies of the world. In such a scenario has been admitted that the foundation of economic growth and long-term development is the exploitation of the productive potential of each actor on the world market; the economic policies and institutional reforms were accepted as basic tools in redefining the quantitative and qualitative coordinate of recovery through competitiveness and sustainable performance.

One of the determinants of competitiveness is the taxation. Assessing the impact of taxation on competitiveness must not be achieved only through the prism of the rates afferent to regulated taxes, but also in terms of the ease with which these taxes can be managed by the business environment (in terms of calculation, declaration and payment) and of the degree of collection, number of fiscal and para-fiscal elements etc.

The main objective of the research was to identify the extent of the impact of taxation on the global competitiveness of European Union member states. To achieve this goal, the paper is structured as follows: the first section presents the state of 
knowledge in the field; section two presents the methodological coordinates of the research on global competitiveness; the third section presents the global competitiveness index for EU member states; in the fourth section is identified the magnitude of the taxation impact on the global competitiveness; the last section summarizes the conclusions and shows the limits and future directions of research.

\section{The state of knowledge in the field}

The complexity of contemporary economies, diversification and specialization, technical progress, increased dependency on raw materials, crises and increasing concerns on risk reduction while maximizing the gains/benefits have redefined the role, dynamics and structure of indicators for assessing global competitiveness.

Barre (1976) first talked about competitiveness for characterizing the competitive economic policy oriented to the exterior. Recent research has brought additional contributions in international competitiveness. The competitiveness was defined as: a) the ability to create wealth (Kao, 2008; Onsel, 2008), being considered a relevant indicator for assessing countries and regions; b) a high standard of living in a country with the lowest rate of unemployment (European Competitiveness Report, 2010); c) a set of institutions, policies and factors that determine the level of productivity of a country (Sala-I-Martin et al., 2009). Summing up the theoretical and empirical research results, it emerges the idea that winning more profitable positions depends on variables such as: performance, welfare, efficiency, innovation and sustainability (Herciu, 2013).

In order to ensure progress in research was not carried out a strict limitation on the positive heuristic, but was noticeable also the negative heuristics. The most "fierce" critical of the concept of competitiveness was Krugman (1996), which said that the definitions are "elusive and meaningless when related to national economies; for the economies with low international trade, competitiveness is a fun way of saying productivity”. Subsequent work challenged Paul Krugman's arguments and showed that international competitiveness is a function of savings and investments, respectively a function of fiscal and monetary policy mix (Howes \& Singh, 2000).

In retrospect, through the filter critical rationalism, we appreciate that the solidity of international competitiveness theory has proven its strength and importance. Noteworthy is the fact that the research path was not unidirectional, but there were turns in plan of the debates.

\section{Methodological coordinates of the research on global competitiveness}

To appreciate the impact of taxation on global competitiveness we relate to reports by World Economic Forum (Schwab, 2013, 2014). According to the methodology of these reports, to assess competitiveness were analyzed:

- The determinant factors (called pillars of competitiveness): (1) basic factors (institutions, infrastructure, macroeconomic environment, health and primary education); (2) increasing efficiency factors (professional improvement, efficiency and size of the markets - of goods, labor and financial - receptiveness to new technologies); (3) innovation factors (quality and complexity of business and innovation);

- The development stages of each economy: a) stage 1 - guidance on the basic factors of competitiveness; b) transition from stage 1 to stage 2; c) stage 2 - competitiveness focus on efficiency; d) transition from stage 2 to stage 3 ; e) stage 3 - based on innovation. 
The influence of taxation on global competitiveness index is caught in the second group of factors (related to efficiency). In the category of determinants of efficiency were included: higher education and training; goods market efficiency; labor market efficiency; financial market development; technological readiness; market size.

To assess the goods market efficiency were considered the following issues: intensity of local competition; extent of market dominance; effectiveness of anti-monopoly policy; effect of taxation on incentives to invest; total tax rate (percent of profits); number procedures to start a business; number days to start a business; agricultural policy costs; prevalence of trade barriers; trade tariffs (percent of duty); prevalence of foreign ownership; business impact of rules on FDI; burden of customs procedures; imports as a percentage of GDP; degree of customer orientation and buyer sophistication.

To assess the labor market efficiency were considered the following issues: cooperation in labor-employer relations; flexibility of wage determination; hiring and firing practices; redundancy costs, weeks of salary; effect of taxation on incentives to work; pay and productivity; reliance on professional management; country capacity to retain talent; country capacity to attract talent; women in labor force, ratio to men.

As shown, the impact of the fiscal elements is quantified in order to assess the efficiency of the goods market and labor market, and then to be found in one of the three subindexes that were the basis for determining the global competitiveness index (GCI). In brief, the influence of fiscal factors on GCI is shown in Figure 1.

\begin{tabular}{|c|c|c|c|}
\hline Factors & Pillar & Subindexes & Index \\
\hline $\begin{array}{l}\text { Public institution } \\
\text { Private institution }\end{array}$ & Institutions & \multirow{2}{*}{$\begin{array}{l}\text { Basic } \\
\text { requirements }\end{array}$} & \multirow{9}{*}{$\begin{array}{c}\text { Global } \\
\text { Competitiveness } \\
\text { Index }\end{array}$} \\
\hline$\ldots$ & $\ldots$ & & \\
\hline $\begin{array}{c}\text { Effect of taxation on } \\
\text { incentives to invest }\end{array}$ & \multirow{3}{*}{$\begin{array}{l}\text { Goods market } \\
\text { efficiency }\end{array}$} & \multirow{5}{*}{$\begin{array}{l}\text { Efficiency } \\
\text { enhancers }\end{array}$} & \\
\hline $\begin{array}{c}\text { Total tax rate (percent of } \\
\text { profits) }\end{array}$ & & & \\
\hline$\ldots$ & & & \\
\hline $\begin{array}{c}\text { Effect of taxation on } \\
\text { incentives to work }\end{array}$ & \multirow[t]{2}{*}{$\begin{array}{l}\text { Labor market } \\
\text { efficiency }\end{array}$} & & \\
\hline$\ldots$. & & & \\
\hline$\ldots$ & Business sophistication & \multirow{2}{*}{$\begin{array}{l}\text { Innovation and } \\
\text { sophistication } \\
\text { factors }\end{array}$} & \\
\hline$\cdots$ & R\&D Innovation & & \\
\hline
\end{tabular}

Figure 1 The transposition of fiscal factors influences in GCI

\section{The image of global competitiveness of the EU Member States}

In order to sketch a picture of how EU countries have managed to cope in the face of new challenges we will relate to the results of reports by the World Economic Forum (Schwab, 2013, 2014) on global competitiveness.

In terms of annual classification on different predefined stages of development of Member States, WEF reports reveal a shy country migration. A progress was made on line of classification only by Slovak Republic (2012/2013) and Estonia (2013/2014), the last one managed to fit in the third stage of development.

According to the latest WEF report (2014/2015), at European Union level, out of the 28 states, two (Romania and Bulgaria) fall into stage two (based on efficiency), five 
fall in the transition stage from efficiency to innovation (Croatia, Hungary, Latvia, Lithuania, Poland), other states (21 in number) fit in the third stage. The image of ordering the EU Member States depending on the size of global competitiveness index is shown in Figure 2.

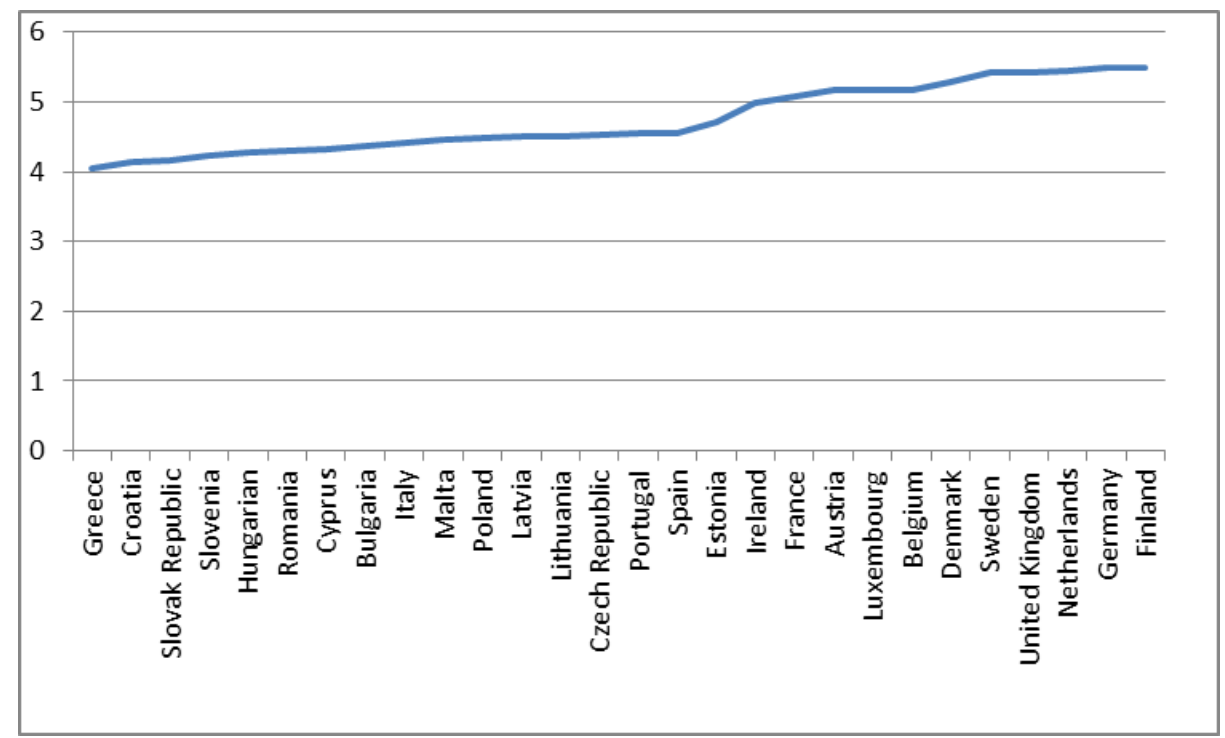

Figure 2 Ranking the EU countries according to the index of global competitiveness (2014/2015)

\section{Analysis of the impact of taxation on global competitiveness}

The impact of the fiscal elements is quantified in order to assess the efficiency of the goods market and the labor market; the pursued fiscal issues were: effect of taxation on incentives to invest (ETII); total tax rate (percent of profits) (TTR) and effect of taxation on incentives to work (ETIW). Table 1 gives the evolution of these influences.

Table 1 Quantifying the impact of fiscal factors on global competitiveness

\begin{tabular}{|r|c|r|r|r|r|r|r|r|r|}
\hline \multirow{2}{*}{} & \multirow{2}{*}{ Country } & \multicolumn{2}{|c|}{ ETII } & \multicolumn{2}{|c|}{ TTR } & \multicolumn{2}{c|}{ ETIW } & \multicolumn{2}{c|}{$\begin{array}{c}\text { DGP per capita } \\
\text { (thousand USD) }\end{array}$} \\
\cline { 2 - 11 } & $2013 /$ & $2014 /$ & $2013 /$ & $2014 /$ & $2013 /$ & $2014 /$ & $2013 /$ & $2014 /$ \\
2 & 2014 & 2015 & 2014 & 2015 & 2014 & 2015 \\
\hline 1 & Austria & 3.9 & 3.6 & 53.1 & 52.4 & 3.2 & 2.9 & 47.1 & 48.9 \\
\hline 2 & Belgium & 3.3 & 3.1 & 57.7 & 57.5 & 2.3 & 2.3 & 43.6 & 45.3 \\
\hline 3 & Bulgaria & 3.4 & 3.6 & 28.7 & 27.7 & 3.3 & 3.4 & 7.0 & 7.3 \\
\hline 5 & Croatia & 2.3 & 2.1 & 32.8 & 19.8 & 2.3 & 2.2 & 12.9 & 13.5 \\
\hline 4 & Cyprus & 4.2 & 4.4 & 23.0 & 22.5 & 4.2 & 4.4 & 26.3 & 24.7 \\
\hline 6 & Czech Republic & 2.7 & 3.3 & 49.2 & 48.1 & 2.7 & 3.1 & 18.5 & 18.8 \\
\hline 7 & Denmark & 3.2 & 3.2 & 27.7 & 27.0 & 2.8 & 2.7 & 56.2 & 59.1 \\
\hline 8 & Estonia & 5.0 & 4.9 & 67.3 & 49.4 & 4.3 & 4.3 & 16.3 & 19.0 \\
\hline 9 & Finland & 4.0 & 3.9 & 40.6 & 38.8 & 3.8 & 3.6 & 46.0 & 47.1 \\
\hline 10 & France & 2.6 & 2.8 & 65.7 & 54.7 & 2.8 & 2.9 & 41.1 & 43.0 \\
\hline 11 & Germany & 4.1 & 4.1 & 46.8 & 49.4 & 3.7 & 3.7 & 41.5 & 45.0 \\
\hline 12 & Greece & 2.4 & 2.4 & 44.6 & 44.0 & 2.5 & 2.5 & 22.0 & 21.8 \\
\hline
\end{tabular}



UNION MEMBER STATES

\begin{tabular}{|l|c|r|r|r|r|r|r|r|r|}
\hline 13 & Hungarian & 2.7 & 2.8 & 50.3 & 49.7 & 2.7 & 2.8 & 12.7 & 13.4 \\
\hline 14 & Ireland & 4.6 & 4.5 & 26.4 & 25.7 & 3.5 & 3.4 & 45.8 & 45.6 \\
\hline 15 & Italy & 2.1 & 2.0 & 68.3 & 65.8 & 2.0 & 1.9 & 33.1 & 34.7 \\
\hline 16 & Latvia & 3.7 & 3.8 & 36.6 & 35.9 & 3.1 & 3.3 & 13.9 & 15.2 \\
\hline 17 & Lithuania & 3.2 & 3.1 & 43.7 & 43.1 & 3.0 & 2.9 & 14.0 & 16.0 \\
\hline 18 & Luxembourg & 5.3 & 5.3 & 21.0 & 20.7 & 5.2 & 5.1 & 107.2 & 110.4 \\
\hline 19 & Malta & 4.2 & 4.3 & 41.6 & 41.0 & 4.0 & 4.2 & 20.8 & 22.8 \\
\hline 20 & Netherlands & 4.6 & 4.6 & 40.1 & 39.3 & 3.8 & 3.7 & 46.1 & 47.6 \\
\hline 21 & Poland & 3.1 & 3.3 & 43.8 & 41.6 & 3.3 & 3.4 & 12.5 & 13.3 \\
\hline 22 & Portugal & 2.6 & 2.9 & 42.6 & 52.3 & 2.4 & 2.8 & 20.1 & 20.7 \\
\hline 23 & Romania & 2.6 & 2.9 & 44.2 & 42.9 & 2.1 & 2.5 & 7.9 & 8.9 \\
\hline 24 & Slovak Republic & 3.1 & 3.2 & 47.9 & 47.2 & 2.7 & 2.9 & 16.9 & 17.7 \\
\hline 25 & Slovenia & 2.9 & 2.8 & 34.7 & 32.5 & 2.7 & 2.5 & 22.2 & 22.7 \\
\hline 26 & Spain & 3.1 & 2.9 & 38.7 & 58.6 & 3.0 & 2.8 & 29.2 & 29.1 \\
\hline 27 & Sweden & 4.5 & 4.3 & 53.0 & 52.0 & 4.4 & 4.2 & 55.1 & 57.9 \\
\hline 28 & United Kingdom & 4.3 & 4.3 & 35.5 & 34.0 & 4.0 & 4.1 & 38.5 & 39.5 \\
\hline
\end{tabular}

ETII - Effect of taxation on incentives to invest; TTR - Total tax rate, \% profits; ETIW Effect of taxation on incentives to work

Source: Processed after Schwab, K. (ed.), The Global Competitiveness Report 2013-2014, Report 2014-2015, World Economic Forum, Geneva.

a) As regards effect of taxation on incentives to invest (ETII) on goods market efficiency, respectively on global competitiveness index, the reports show modest variation in each Member State (2013/2014). Positive evident evolutions, with relevant impact on the global competitiveness index, presents France, Portugal, Romania and the Czech Republic (Figure 3). Looking through the prism of all European Union member countries are observed major differences. At the bottom of the ranking are Italy, Croatia and Greece, and the top of the ranking is Netherlands, Estonia and Luxembourg. The competitiveness of countries at the bottom of the ranking is affected by the tax burden and restrictive and discriminatory rules on foreign direct investment (FDI).

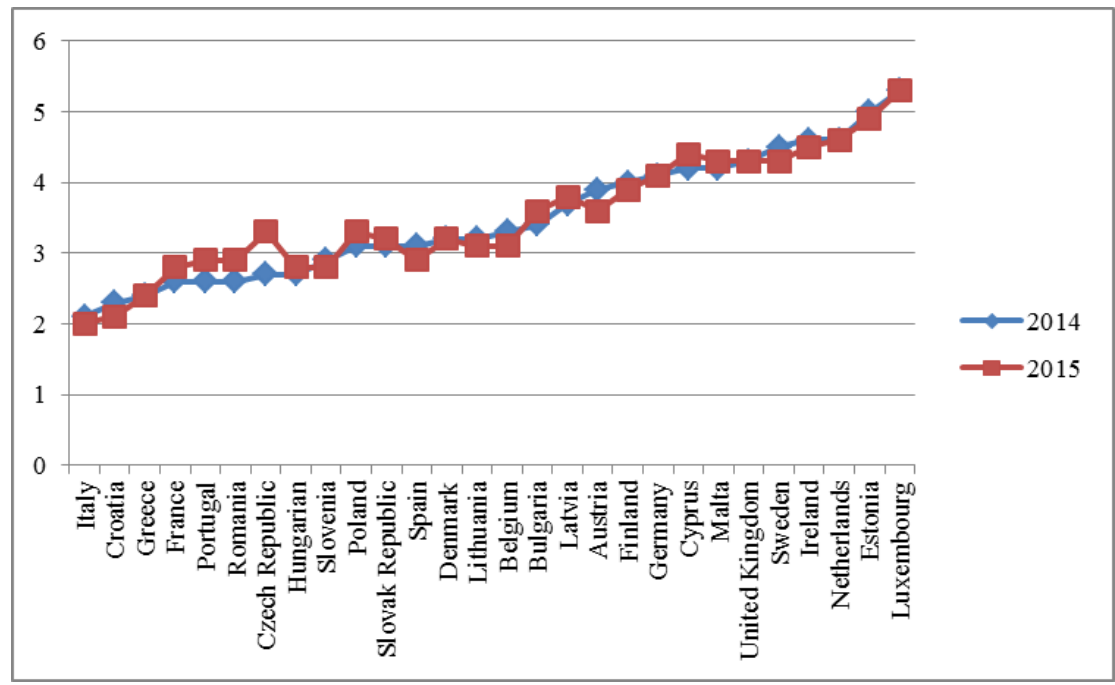

Figure 3 Effect of taxation on incentives to invest 
b) The analysis of tax burden chromatic on profit configures a wide range, including both somber tones (economies whose tax rate exceed 50\%) and lighter tones (economies whose tax rate gets down to 20\%) (Figure 4). Favorable evolutions (towards reducing taxation) were recorded by Croatia and Estonia. According to a working document of the European Commission (EC, 2014) there can be identified the causes of this evolution: Estonia had a strong budgetary position; Croatia has taken measures so that the structure of taxation should no longer focus on work but on taxes less harmful to economic growth.

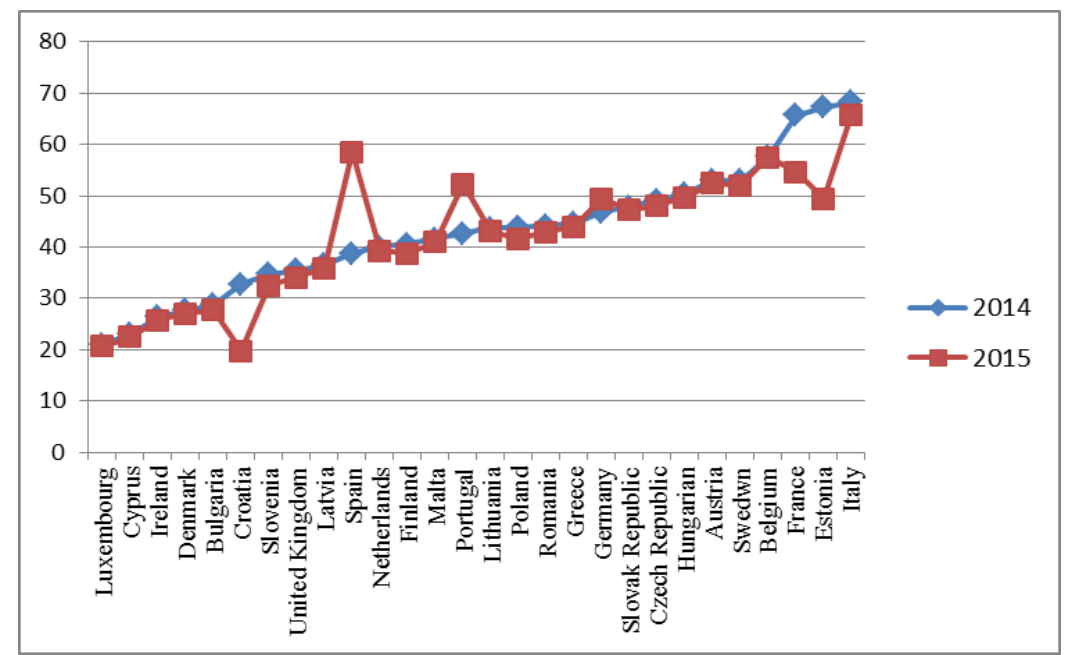

Figure 4 Total tax rate

For a meaningful interpretation of the total tax rate we followed its correlation with GDP per capita (for 2015); this correlation allows assess the level of supportability of the tax burden. Figure no. 5 reveals that countries with a total tax rate higher than $40 \%$ and a GDP per capita below USD 20,000 are presenting the lowest level of supportability (Romania, Poland, Hungary, Lithuania etc.). At the opposite pole is Luxembourg that has the highest GDP/capita and the lowest overall tax rate.

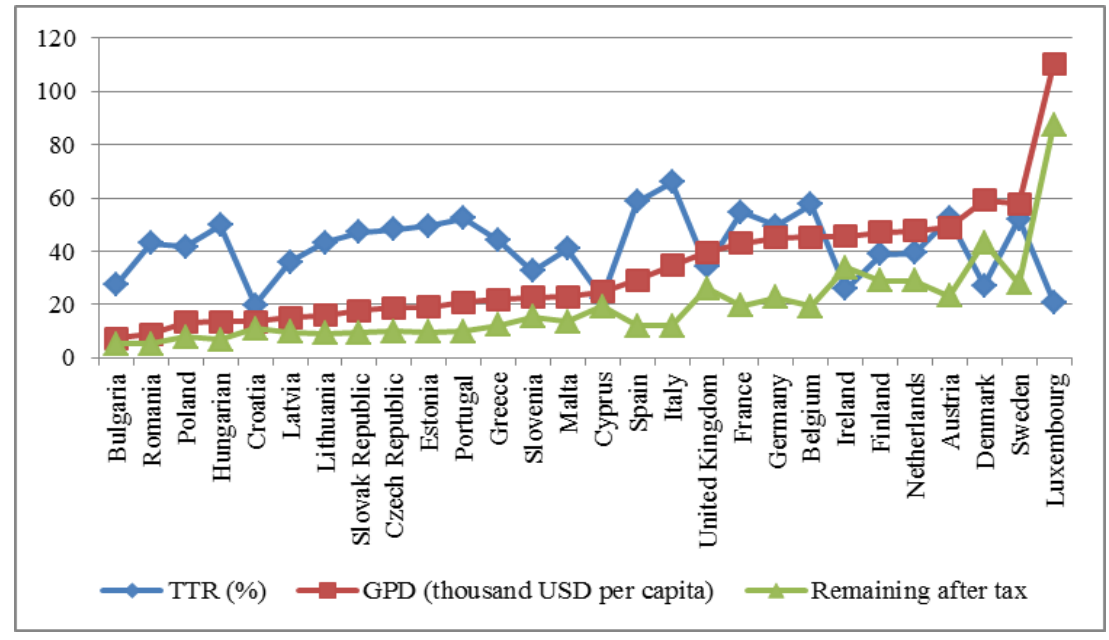

Figure no. 5. TTR, GPD per capita (2014/2015) 
Croatia has a special situation; although it has recorded one of the lowest levels of profit tax, taxation remains burdensome due to the low level of GDP per capita. Therefore, this EU Member State will have to continue strengthening the institutional framework and promote the efficiency of goods and services market.

c) Effect of Taxation on incentives to work (ETIW) put their mark on the efficiency and flexibility of the labor market, which - in turn - influences global competitiveness. In the bottom of the ranking countries (Italy, Romania, and Belgium) high levels of labor taxation affects economic competitiveness (Figure 6). At the opposite pole is Luxembourg with one of the most generous labor tax systems in the EU.

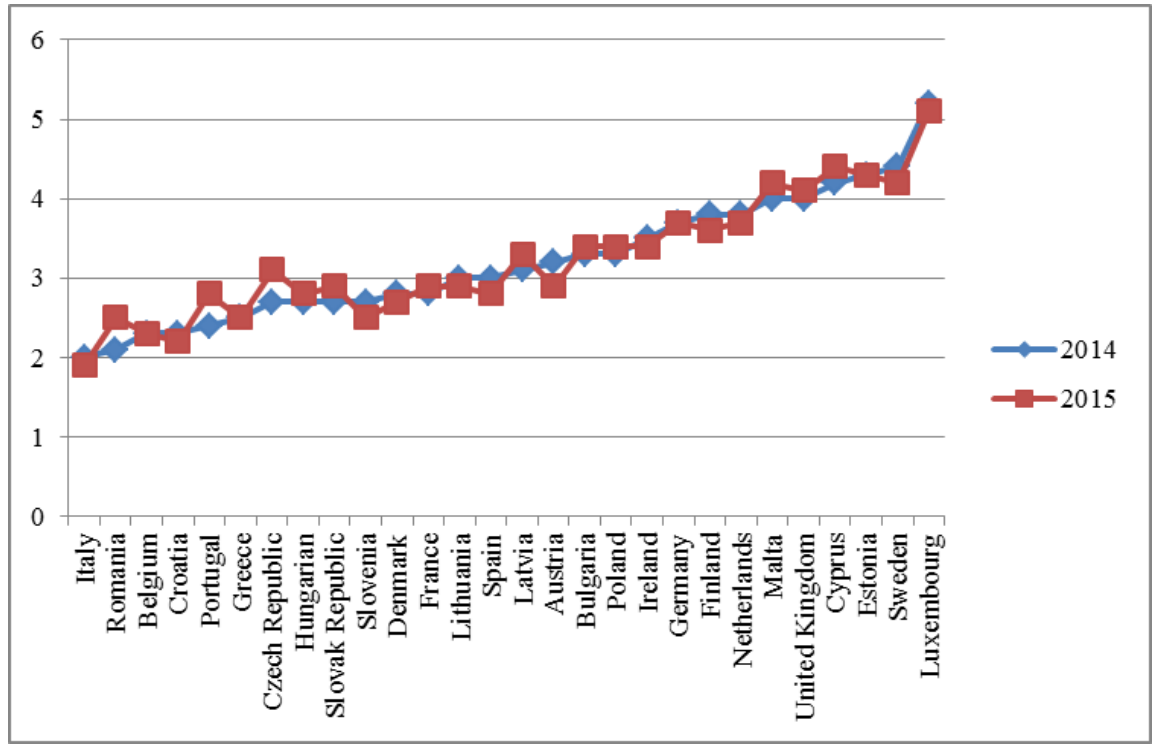

Figure no. 6. Effect of taxation on incentives to work (ETIW)

\section{Conclusions}

The competitiveness has been and remains a priority in terms of scientific debate, but also a major concern for all world economies. National fiscal policies have a major impact on the effective functioning of markets, impact that is transmitted to global competitiveness. For a meaningful interpretation, the tax burden must be correlated with the volume of taxable mass.

In the European Union, the global competitiveness index varies between 4.04 (Greece) and 5.5 (Finland); at the bottom of the ranking is Greece, Croatia, Slovakia and Slovenia, where prevails the influence of basic factors and of increase efficiency factors. At the top of the ranking is the UK, Netherlands, Germany and Finland, falling in the third stage of development (based on innovation).

The analysis of the impact of taxation on global competitiveness for European Union Member States allows the following conclusions:

a) the fiscal policies supporting investment contributes positively to competitiveness in countries such as Luxembourg, Estonia, Netherlands, Ireland, UK; the states where the effects of tax incentives on investment bring the smallest contribution to competitiveness are Italy, Croatia and Greece; the dynamic analysis found an increase in concerns on this matter in France, Portugal, Romania and the Czech Republic; 
b) knowing of the total tax rate (calculated as a percentage of profit) allows isolated interpretation; the correlation with GDP per capita allowed to observe the supportability of the tax burden; the states with a total tax rate higher than $40 \%$ and a GDP per capita below USD 20,000 are presenting the lowest level of supportability (Romania, Poland, Hungary, Lithuania etc.); at the opposite pole is Luxembourg that has the highest GDP/capita and the lowest overall tax rate;

c) the level of labor taxation affects the efficiency and flexibility of the labor market, respectively the global competitiveness; the most generous system of taxation of labor in the EU is found in Luxembourg; at the opposite pole is Italy, Romania and Belgium.

Limitations and future directions of research. The research is only using the information provided by reports of the World Economic Forum. To overcome this limit in future research we consider to also analyze the information provided by other papers (sources) but also to make projections on the impact of taxation on the global competitiveness of European Union member states.

\section{References}

Barre, R. (1976), Economie politique, vol II, Paris, PUF.

European Union (2010), European Competitiveness Report 2010, Luxembourg, Publications Office of the European Union.

Herciu, M. (2013), Studii post-doctorale în economie, vol. V, Studii şi cercetări privind impactul globalizării asupra structurii şi dinamicii economiilor, Bucureşti, Editura Academiei Române.

Howes C., Singh, A. (eds.) (2000), Competitiveness Matters. Industry and Economic Performance in the U.S., University of Michigan Press.

Kao, C., Wu, W., Hsieh, W. J., Wang, T. Y., Lin, C., Chen, L. H. (2008), Measuring the National Competitiveness of Southeast Asian Countries, European Journal of Operational Research, 187, 613-628.

Krugman, P. (1996), Making Sense of the Competitiveness Debate, Oxford Review of Economic Policy, 12(3), 17-25.

Onsel, S., Ulengin, F., Ulusoy, G., Aktas, E., Kabak, O. Topcu, Y. I. (2008). A New Perspective on the Competitiveness of Nations, Socio-Economic Planning Sciences, 42, 221-246.

Sala-I-Martin, X., Blanke, J., Drzeniek Hanouz, M.,Geiger, T., Mia, I. (2009), The Global Competitiveness Index 2009-2010. Contributing to Long-Term Prosperity amid the Global Economic Crisis, Geneva, World Economic Forum.

Schwab, K. (ed.) (2013), The Global Competitiveness Report 2013-2014, Geneva, World Economic Forum.

Schwab, K. (ed.) (2014), The Global Competitiveness Report 2014-2015, Geneva, World Economic Forum. 